\title{
A ESCOLA PÚBLICA LAICA EM PORTUGAL: A REPÚBLICA E OS REPUBLICANOS - UM INQUÉRITO AOS PROGRAMAS DOS PARTIDOS REPUBLICANOS (1910-1926)
}

\author{
José António Afonso*
}

\begin{abstract}
RESUMO
No presente texto procuramos refletir sobre o processo de criação da escola pública laica no Portugal republicano. Partiremos da exploração dos programas eleitorais das formações partidárias explicitamente republicanas e resultantes de cisões no Partido Republicano Português (PRP). Esta opção radica na possibilidade de através dessa fonte de informação se proceder a uma aproximação à realidade centrada no modo como os atores republicanos configuraram essa escola-elemento matricial do ideário do PRP -, por um lado, em face das sucessivas conjunturas políticas que assolaram o período de 1910 a 1926, e, por outro lado, como se reconfiguraram as diferentes sensibilidades republicanas face à própria constitucionalização da República.
\end{abstract}

Palavras-chave: República. Partidos políticos. Escola laica.

\begin{abstract}
In this paper we seek to reflect on the process of creating a secular public school in Portugal Republican. We leave the exploration of the electoral programs of training explicitly partisan Republican and resulting splits the Portuguese Republican Party (PRP). This option lies in the possibility of using this source of information is necessary to approximate the reality focused on how actors Republicans configured this school - matrix element of the ideals of PRP - on the one hand, in the face of successive political circumstances that plagued period 1910-1926, and on the other hand, as reconfigured different sensitivities against the republican constitution for the Republic itself.
\end{abstract}

Key words: Republic. Political parties. Secular school.

\footnotetext{
* Doutor em História da Educação pela Universidade do Minho, Braga, Portugal. Professor do Instituto de Educação e Investigador do CIEd - Universidade do Minho, Braga, Portugal. E-mail: joseamm.afonso@gmail.com
} 


\section{Introdução}

A República em Portugal é um acontecimento onde confluem e colidem três processos que com as suas metamorfoses se vão desenvolvendo e reconfigurando. Temos, então, que os projetos que se cruzam manifestam uma matriz republicana que conjunturalmente consubstanciou uma plataforma antimonárquica e anticlerical, revelando, ao longo do tempo, fragilidades que ficam evidentes nas dissidências que se verificaram no Partido Republicano Português; um outro projeto situa-se no campo das forças políticas socialistas, anarquistas e temuma expressão tendencialmente mais visível no quadro do movimento operário e na criação de organizações sindicais, e, por último, o outro projeto é conotado com o elã das organizações católicas, que a partir de certo período se cruzam com as manifestações monárquicas, e que no período republicano ganham paulatinamente uma relativa consistência pela oposição à designada da Lei da Separação.

Interessa-nos neste inquérito observar exclusivamente como as formações partidárias republicanas foram encarando a questão educativa. Sabe-se que a centralidade do projeto educativo é clara no ideário republicano porque responde à exigência de tornar efetiva a igualdade de direitos, permitindo o acesso de todos os cidadãos ao julgamento crítico, condição essencial para a sua autonomia, mas a escola republicana tem, para cumprir, os seus desígnios de ser laica e dissipar todos os préconceitos. Se a laicidade é o fundamento da República, então, a instrução pública tem que assentar na pedra angular de todo o regime republicano, a saber: a separação das Igrejas do Estado. A laicidade implica a liberdade de consciência, partindo da ideia da dignidade da pessoa humana. É com base nestes princípios que o Estado tem que ser neutro em matéria religiosa, porque respeitando a liberdade de consciência garante a independência de todas as Igrejas (Audiner, 2004). Em teoria, todo o republicanismo estrutura-se a partir deste axioma, podendo, contudo, ser declinado de modos diversos, pelo modo como vai configurando os dispositivos que assegurem a justiça através da noção de bem comum, mas também pelas formas como dissemina os fundamentos morais desse autogoverno do povo - a República (id.). 
Em Portugal, o republicanismo foi multiforme atendendo a um conjunto de circunstâncias sociológicas e antropológicas, mas que também desvendam a diversidade idiossincrática dos atores republicanos nas suas respostas aos desafios concretos que a governação foi exigindo, como, ainda, se posicionaram face ao devir da própria República em contexto internacional. Certamente, as clivagens no Partido Republicano são disso testemunho e os Programas e Manifestos que essas novas constelações partidárias produziram, são documentos sociais que indiciam o grau de representação que tinham sobre a Escola laica, mas fundamentalmente sobre a questão religiosa. Tomaremos, então, os Programas partidários na sua dimensão retórica como um modo muito particular de ler a realidade, mas também de construir uma outra realidade - ou seja, de produzir sociedade (Angenot, 2010). Essas posições vão ser referenciadas em função do ciclo eleitoral para o Parlamento ${ }^{1}$, como possibilidade de aferir a disputa no campo da prática democrática plural. Esta é a nossa proposta que ensaiaremos tendo ainda presente que é uma abordagem circunscrita às manifestações escritas expressas em circunstâncias muito particulares da constitucionalização da República Portuguesa, entre 1910 e 1926, e da geração de um mosaico de formações republicanas com sensibilidades muito próprias que se traduziram em expressões partidárias, de duração variável e consistência social díspares (nos Anexos I e II representamse esquematicamente, com base em Leal (2008) e Pinto (2011), o núcleo ideológico de cada uma das três sensibilidades republicanas identificada bem como as formações partidárias resultantes das cisões do P.R.I.), mas que objetivamente se viram confrontadas com outros protagonistas no contexto de uma sociedade tendencialmente moderna.

\footnotetext{
1 Os dados eleitorais são retirados de Pedro Tavares (org.), Materiais para a História Eleitoral e Parlamentar Portuguesa, 1820-1926. Só retivemos a informação para a designada Câmara dos Deputados (e nesta não incluímos a rúbrica que se refere a candidaturas independentes ou de pequenas formações partidárias, designada por “outros"), também não consideramos as eleições para o Senado, ocorridas nas mesmas datas, mas que genericamente são homólogas nos seus resultados, das dos Deputados.
} 


\section{Por uma escola não confessional}

Durante a Monarquia Constitucional, num Estado confessional, as posições políticas dos partidos do poder, nomeadamente, o Partido Progressista e o Partido Regenerador-Liberal ${ }^{2}$, convergem na defesa de um ensino primário obrigatório, reconhecendo que deve estar estatalmente ordenado e ter um sentido prático. Estas duas formações políticas pugnam pela liberdade, tolerância, respeito às leis e moralidades em todos os atos públicos. Outras formações emergem, declarando-se explicitamente como católicas: Partido Legitimista - "católico, patriótico, monárquico" - e Partido Nacionalista - "partido católico". O Partido Legitimista configura a instrução num quadro de uma "monarquia cristã, tradicional e hereditária", apesar do ar moderno que lhe pretende dar, à imagem de outras Nações europeias. A educação religiosa, explicitam, deve exclusivamente ser ministrada pelos párocos. O Partido Nacionalista, configura a "necessidade de conservação do princípio religioso na educação, como essencial para o progresso, dentro da ordem, reconhecendo a lógica dependência, e correlação necessária, entre o progresso e a ordem, entre a ordem e a moral, e entre a moral e a religião, sendo a religião base da moral, a moral fundamento da ordem, e a ordem condição do progresso". Em síntese, defendem a "boa harmonia entre a Igreja e o Estado como sociedades perfeitas que são". Apesar da pretensa hegemonia católica e da tácita convergência de interesses das principais formações políticas, paulatinamente vão surgindo no espaço público posições que colocam em questão a cristalização na escola da sua confessionalidade enquanto desígnio natural e irrefutável.

Em 1886, é esboçado um programa para o Partido Republicano Português onde se defende a "Separação da Igreja e do Estado; abolição do juramento religioso em todos os atos civis ou políticos; restituição à Nação, às províncias e aos municípios dos bens das Igrejas, confrarias e congregações religiosas" e que a "Instrução [deve] ser universal, integral, secular e gratuita, em todos os graus". Na versão de 1891, escreve-se que o "Ensino elementar [é] obrigatório, secular e gratuito", num quadro de

2 Os programas de todos os partidos, no período da Monarquia Constitucional, são retirados de Coelho (1906, pp. 596-652) 
"igualdade civil e política para todos os cultos". O Partido Socialista, no seu programa de 1895, propõe a "Educação de todas as crianças por conta pública e ao mesmo grau de instrução a "Completa abstenção do Estado em matéria religiosa". Os anarquistas, desde 1887, na sua diversidade e nos micro relatos que difundem na sua imprensa, reforçam a ideia de uma "instrução livre" liberta de todos os dogmas. Cada uma destas organizações políticas materializou os seus ideários em escolas que polvilharam o país; umas mais efémeras; outras mais consistentes; todas no seu conjunto formaram uma rede de ensino marcadamente laica e secular. Deve-se, para concluir, evidenciar que os movimentos protestantes marcaram, com os seus colégios, posições de decidida contestação à escola confessional da Monarquia Constitucional (Afonso, 2012).

\section{Um Portugal republicano}

A 5 de Outubro de 1910 a República é proclamada. O nascimento de um Portugal novo vislumbra-se. Os republicanos que derrubaram a Monarquia protagonizavam um projecto laico que visava duas finalidades: liberdade e igualdade e assentava em dois meios imprescindíveis para alcançar esse objectivo: a neutralidade e a separação. No essencial replicavam uma ideia esboçada desde 1880 por Ferdinand Bouisson (1911): um Estado neutro independente dos clérigos que asseguraria a liberdade de todos os cultos e a igualdade de todos os cidadãos, qualquer que fosse a sua pertença religiosa ou não religiosa. As crenças, num ideal de república que dinamizasse a ascensão social, compaginavam-se com a exigência de um cidadão livre, e, no caso português, associava-se indelevelmente a uma pátria revigorada - ou renascida.

A realidade sociológica do país era deveras preocupante: $78 \%$ de analfabetos em 5,5 milhões de habitantes pobres e rurais na sua grande maioria. Portugal apresentava níveis elevados de emigração e caracterizava-se por um despovoamento acentuado de certas áreas do país. Lisboa e Porto exerciam um grande poder de atracção. A industrialização era incipiente e um cenário de estagnação da população activa era patente. Os capitais estrangeiros (franceses, alemães, belgas e essencialmente ingleses) controlavam a indústria e importantes companhias comerciais, 
bancárias e de transportes. Portugal, na expressão de Oliveira Marques (2010), era "pouco mais do que uma colónia em larguíssimos aspectos". A indústria do tabaco apresentava a maior concentração operária, mas indústrias como as de conservas e a têxtil iam adquirindo maior peso económico e empregando mais mão-de-obra, assim para as conservas, regista-se o valor de 16 mil operários e para a têxtil, em 1914, rondaria os 40 mil operários, o que representava cerca de $1 / 3$ do operário fabril. No entanto, nota-se que outras indústrias emergiam, como a da moagem (com 18 mil operários), a da metalurgia (com 9 mil operários) e a corticeira (com 7 mil operários). A indústria química e a de cimento despontavam. Estas indústrias concentravam-se em Lisboa, península de Setúbal, Porto e Minho, e destinavam-se a abastecer o mercado interno e o Ultramar. O comércio externo dependia dos produtos agrícolas e as exportações faziam-se quase exclusivamente com a Inglaterra (70\%). A organização paternalista do trabalho era patente.

A viciosa organização da propriedade (minifúndio a Norte e latifúndio a Sul) ditaria uma crónica e insanável "questão agrícola". O predomínio dos pequenos camponeses e rendeiros era uma constante. O comércio também estava tolhido por circuitos asfixiados. As infraestruturas eram débeis e anquilosadas. Face a estes constrangimentos, regista-se, entre 1900 e 1913, um aumento dos níveis de produtividade do trabalho quer para o sector agrícola, quer para o sector industrial, na ordem dos $2 \%$ ano (Marques, 2010).

A burguesia, a pequena burguesia e os "novos-ricos" contrastavam com o "povo miúdo", pelo fausto, opulência, colagem ao Estado, homogamia cultural. Léon Poinsard (1912) diz-nos que o país "permanecia como que abandonado" face a uma elite que se reproduzia na "sua aparência de ocupação sem grande proveito", incapaz, portanto, de fomentar o "espírito nacional" e não compreendendo que "todas as manifestações da vida são hoje essencialmente internacionais". Nota o autor da "monografia das famílias portuguesas" que a educação é, sem dúvida, o factor que dita a desorganização do país.

A condição da mulher e incontornavelmente o domínio hegemónico da Igreja Católica toldam Portugal numa ambiência caracterizada pela obediência, a pobreza e o conformismo. O peso do catolicismo sentia-se no 
âmbito simbólico - superstição e temeridade - como no aspecto social: uma sociedade entrelaçada numa sociabilidade marcada pelo excessivo peso da religião na regulação social e de uma Igreja minimamente distanciada do poder político - o regalismo é a fórmula de perpetuação da governança que o catolicismo em Portugal apadrinhou de modo explícito.

A questão colonial e a questão financeira, são outras duas fragilidades que os republicanos herdaram.

As frentes prioritárias que a República teve que debelar foram criar uma República Social e uma Escola, capaz de ser o dínamo do projecto laico, em simultâneo com reformas inadiáveis no âmbito económico (indústria e agricultura), exploração racional dos recursos das Colónias e saneamento das contas públicas - equilíbrio orçamental.

\section{A emergência da escola pública laica}

A dimensão social do projecto republicano marca-se por um conjunto de dispositivos normativos, que no contexto do Governo provisório, se preocupam com a família, os menores, a mulher e o divórcio, a assistência social como também a expressão da manifestação das reivindicações sociais, como por exemplo, o direito à greve. Querem ainda cumprir o processo de secularização da sociedade, como fórmula de assegurar o princípio da igualdade de direitos dos cidadãos e da universalidade da ação desenvolvida no sentido do interesse público. Todo o ideário republicano plasma-se indelevelmente na assunção de novas sociabilidades, de que a republicanização do calendário (como paradigma de um novo entendimento do tempo) é um dos índices mais representativo (Andrade \& Torgal, 2012).

A linha mais assumidamente anti-clerical vai vincando as suas posições para assegurar um "mínimo republicano". É sobretudo no âmbito da Escola que de forma indelével se vão fazer sentir os efeitos da anti-religiosidade, que se vincam por toda uma série de normativos, que bastante cedo foram promulgados, e que se concentram na expurgação de qualquer manifestação religiosa da esfera do Estado (Costa \& Marcos, 2010; Pintassilgo, 2010). 
Assim, desde o revitalizar da legislação de 1759, 1767 e 1834 sobre as ordens religiosas, decisão tomada a 8 de Outubro de 1910, até à lei de 29 de Abril de 1911, designada por Separação do Estado das Igrejas, um conjunto significativo de normativos prende-se com o Ensino, de que se destacam o decreto de 22 de Outubro de 1910 - proibição do ensino da doutrina cristã nas escolas primárias e primárias superiores - onde se pode ler no seu Artigo 20: "O ensino da moral nas escolas primárias e normais primárias será feito sem auxílio de livro, intuitivamente, pelo exemplo da compostura, bondade, tenacidade e método de trabalho do professor, e pela explicação de factos de valor cívico e moral, que imprimam no carácter dos alunos o sentimento de solidariedade social". O decreto de 29 de Outubro de 1910, declara a neutralidade do ensino em matéria religiosa, e o decreto de 29 de Março de 1911 - Reorganização dos serviços de instrução primária - assertivamente enfatiza: "A República libertou a criança portuguesa, subtraindo-a à influência jesuítica, mas precisa agora de a emancipar definitivamente de todos os falsos dogmas, sejam os de moral ou de ciência, para que o seu espírito floresça na autonomia regrada, que é a força da civilização". Mais à frente pode-se ler: "A religião foi banida da escola. Quem quiser que dê à criança, no recanto do lar, porque o Estado, respeitando a liberdade de todos, nada tem com isso. A moral das escolas, depois que a República se fundou, só tem por base os preceitos que regulam a justiça entre os homens e a dignidade dos cidadãos. Varreu-se da pedagogia nacional todo o turbilhão de mistérios, de milagres e de fantasmas que regulavam, até então, o destino mental das crianças". Enfaticamente proclama: "A escola vai ser neutra. Nem a favor de Deus, nem contra Deus. Dela se banirão todas as religiões, menos a religião do dever, que será o culto eterno desta nova igreja cívica do Povo". Neste decreto explicitam-se os princípios pedagógicos que devem nortear o ensino na escola primária: "tem de ser intuitivo, tanto quanto possível experimental sem que se perca de vista o desenvolvimento integral de todas as faculdades". Mas o decreto é inovador quanto à missão da escola ao instituir o pré-escolar e o primário superior. A escola é obrigatória (ensino primário elementar) e gratuita (ensino primário elementar, complementar e superior).

Em 1911, a população com mais de 10 anos alfabetizada cifrava-se nos 30\%. Em 1910 a taxa de escolarização da população entre os 9 e os 15 anos rondava os 19\%. O analfabetismo, em 1911, na população portuguesa com 
mais de 7 anos, era de 70\% - e frequentemente adjectivado como "pavoroso cancro", "nossa vergonhosa inferioridade" e "falta de patriotismo".

As classes populares estavam afastadas do processo de escolarização, penalizando mais as zonas rurais. A rede escolar era lacunar, deficitária e instalada maioritariamente em edifícios em péssimas condições. Anquilosada pedagogicamente e marcadamente, ainda, influenciada por práticas de cariz assumidamente confessional.

Fazendo jus a um princípio inabalável, estabelecido desde o programa republicano de 1886 - "derramamento da instrução secular, universal e gratuita" -, a política educativa republicana era democrática e pautada pela justiça. A escola pública configurava-se assim com um espaço de liberdade e progresso, ou como reiterava Tomás da Fonseca no Almanach de O Mundo para 1914: "hoje a República quer a escola como base de toda a sua obra".

O período entre 1911 e 1914 foi particularmente difícil em termos de consolidação das políticas republicanas. Instabilidade política que culminou com a fragmentação do Partido Republicano Português. Surto de greves. Revoltas armadas dos monárquicos exilados. A opção incontornável pelo equilíbrio das finanças. Recrudescimento da oposição católica às medidas do Governo provisório e reacção vigorosa dos governantes - de que se pode referir o texto preambular do Relatório Apresentado à Assembleia Nacional Constituinte pelo Ministro dos Negócios Estrangeiros: "Proclamada a República, não tardou, porém, muito que os agentes da reação clerical, de que o país se libertara, e os que haviam sofrido nos ilegítimos interesses que o novo regime não permitia se continuassem usufruindo, encetassem a luta contra nós, especialmente espalhando notícias falsas para descrédito da República e do país" - negando qualquer legitimidade às suas posições, reafirmando o seu laicismo, estribado em argumentos nacionalistas, positivistas e cientificistas, que configurou um ataque à Religião, ultrapassando o campo das relações institucionais. No quadro da estabilização política, são convocadas eleições para a Assembleia Constituinte. O Partido Republicano Português ${ }^{3}$

3 A informação sobre os programas políticos é retirada, salvo indicação em contrário, de Leal (2008. p. 135-355). Em ANEXO III apresenta-se uma listagem das formações partidárias republicanas identificadas. 
consegue $97,9 \%$ dos votos. Uma missão imprescindível será a elaboração de Constituição da República. Verifica-se que os republicanos estão já fragilizados pela emergência de sensibilidades no seu seio. Uma prova desse clima entre as fações são os debates preliminares para a elaboração da Constituição e muitas das questões abertas perdurarão ao longo de toda a $1^{\text {a }}$ República, ora latentes, ora emergindo no espaço público de forma abrupta.

Muita da polémica então surgida vai, portanto, revelar-se fraturante do próprio Partido (Cunha, 2011, pp. 49-53; Matos, 2010, pp. 11-38; Pinto, 2010; Ventura, 2011). A Assembleia, contava com uma tímida presença socialista $(0,8 \%)$ e de outras personalidades independentes $(1,3 \%)$ pelo que as grandes tensões se geraram entre republicanos - mesmo que um número significativo fosse conotado com a Maçonaria e muitos deles tivessem militado nos partidos dominantes na Monarquia Constitucional, vulgarmente conhecidos por adesivos - tendo, contudo, prevalecido uma "visão moderada e conservadora da República" (Pinto, 2010, p. 11).

Preparando-se as eleições de 1911, afloram já no seio dos republicanos as sensibilidades, assim um manifesto subscrito por "velhos republicanos" (in O Intransigente, 15 Maio 1911, p. 1), apela a uma "aliança de todos os portugueses honrados, qualquer que tivesse sido o seu passado político e qualquer que seja a sua classe especial, quaisquer mesmo que sejam as suas opiniões particulares, desde os conservadores aos radicais, qualquer que seja a sua fé religiosa e seja qual for o critério filosófico doutrinário a que subordinam o seu modo de pensar e a sua maneira de sentir, contando que estejam de acordo nos princípios fundamentais a cuja disciplina a República Portuguesa se submeteu desde o primeiro instante da sua existência". O "Manifesto ao eleitorado português", liminarmente identifica como axiais a Ordem e o Trabalho e não deixa de sublinhar que se deva "cuidar escrupulosamente da educação e da instrução pública". Das candidaturas de independentes, duas, a título de exemplo, podem-nos guiar no fervilhar que agitava as hostes republicanas. Alberto Souto (in Cartaz, 1911) é explícito no programa que pretende levar para a Constituinte: "Ordem e Progresso, Trabalho e Liberdade, Seriedade e Consciência", no entanto, levanta o véu sobre algumas das suas preocupações, e entre elas está a Lei da Separação; cauteloso escreve: "Cumpre a todos acatá-la. É uma lei para o momento, mas que deve ser prontamente remodelada logo 
que o país se mostre sereno e confinado". Prossegue: "Por mim desejo uma lei mais liberal, uma verdadeira Lei da Separação, em que se dê à igreja toda a liberdade e o gozo dos objetos de culto dentro da máxima responsabilidade e do pleno direito de fiscalização do Estado". O outro candidato, Alberto Coutinho (in Cartaz, 1911), vai no mesmo sentido, reconhecendo, no entanto, que "o Governo provisório da República se tem empenhado em decretar leis que muito interessam à nossa vida social (...) entendo, todavia, que essas leis têm que ser cuidadosamente revistas nas futuras Constituintes". Ambos os candidatos, nos prólogos das suas candidaturas, tecem louvores à República e, com ênfase, destacam os seus passados republicanos e as suas qualidades cívicas.

Desde 1910, uma formação republicana - Partido Republicano Radical Português - propagandeava o seu Programa, incluindo nela um capítulo sobre "Instrução", onde taxativamente defendia o "ensino primário obrigatório e gratuito", baseado num "sistema de ensino racional tendente a despertar nas crianças o espírito de observação e energia da vontade" e com a "exclusão absoluta de qualquer confissão religiosa nas escolas".

Uma outra formação política, o Agrupamento Político Integridade Republicana, criado em 1911, no Programa que fez circular, propunha a "Reforma de todo o ensino, tornando-o utilitário e prático", pela "cientificação de toda a instrução, libertando-a de toda e quaisquer superstições" com o objetivo de "robustecer e levantar o génio e o carácter do povo português" e relativamente aos "Cultos" afirma que "O Estado garante o exercício de todos que não ofendam a moral e não ataquem os direitos individuais e sociais", propondo-se o "Estabelecimento de tudo quanto for conducente a aperfeiçoar e completar a Lei da Separação da Igreja e do Estado e a sua execução".

O Partido Republicano Português, apresenta-se com o seu Programa de 1891, onde defende o "Ensino elementar obrigatório, secular e gratuito", inserido num quadro constitucional de fixação das "garantias individuais" ou "liberdades essenciais" - concebidas como "instrumento das garantias políticas e atos civis" - onde destaca: "liberdade de consciência, e igualdade civil e política para todos os cultos".

A Constituição é aprovada em 18 de Agosto de 1911.

Relativamente à Reforma da Instrução Primária manteve-se um 
consenso, mas quanto à Lei da Separação as reservas levantadas foram muitas, tendo prevalecido um relativo equilíbrio de posições quanto à necessidade de a tornar menos "agressiva", ou como era constantemente reiterado: o princípio da Separação era reconhecido, mas a lei, essa, deveria ser modificada (Matos, 2011, pp. $201 s q$.). Uma expressão deste sentimento larvar encontra eco nas palavras de Narciso Alves da Cunha - um dos três padres católicos que militavam no Partido Republicano Português com assento nas duas Câmaras, a dos Deputados e no Senado - que em entrevista ao jornal A Capital, 14 Junho 1911, diz: "Pela minha qualidade de presbítero, uma das leis promulgadas pelo governo provisório que merecerá as minhas referências é a da separação da Igreja do Estado. A separação é, quanto a mim, absolutamente legítima, e nela não vejo nenhum inconveniente. Desde que a Igreja ou o Estado não possam ou não estejam nas condições de viver isolados, separados, mal da Igreja, ou mal do Estado. Portanto, em princípio, estou absolutamente concorde. A lei tem algumas asperezas que talvez possam ser limadas, e que, em meu entender, convém mesmo que o sejam para não abrir barreiras entre o povo das aldeias e a República." (in Pacheco, 2012, p. 195)

No entanto, as principais cisões no Partido Republicano vão-se verificar aquando das Presidenciais, em 1912. Face à intransigência de encontrar um nome comum que incorporasse a ideia de República, na sua dimensão de renascimento de Portugal, três estruturas partidárias surgem: uma, mais à esquerda, encabeçada por Afonso Costa, o Partido Democrático (na continuidade do PRP); outra, situada no centro, liderada por António José de Almeida, o Partido Evolucionista, e, uma outra, à direita, o Partido Unionista (ou União Republicana), presidida por Brito Camacho.

Numquadrodeinstabilidadepolíticasurgemaseleiçõesde 1915, onde o Partido Democrático obtém $65 \%$ dos votos, o Partido Evolucionista, 16\%, o PartidoUnionista, 9,2\%, oPartido Socialista, 1,2\% e as forças católicas, $0,6 \%$.

\footnotetext{
4 Muitas outras posições neste sentido foram expressas e que convergiam na assunção de que a República devia ser obra, para que as populações fossem galvanizadas para o projeto, rompendo-se as fronteiras urbanas (e citadinas) da República. Também se expressava com relativa consistência que a Lei da Separação deveria ser para a sociedade e não para os republicanos - aliás, argumento extensível a toda a dinâmica da República.
} 
O Partido Democrático salvaguardava no seu Programa, os "Direitos e Garantias dos Cidadãos", a "Liberdade de pensamento; a Igualdade civil e política para todos os cultos sob a fiscalização do Estado", bem como a "Liberdade completa de reunião e associação", esclarecendo, no entanto, que defendia a "atual Lei da Separação do Estado das igrejas, como penhor da plena liberdade de consciência e da supremacia do poder civil" e propunha um "Referendum legislativo adaptado ao desenvolvimento da instrução e da educação cívica". No que se refere à "Educação e Instrução", reitera que o "Ensino [é] laico no sentido rigoroso deste termo" e que o "Ensino elementar [é] obrigatório e absolutamente gratuito", devendo contemplar a "Obrigatoriedade do canto coral e do desenho", este capítulo é completado com a seguinte anotação: "Missões de propaganda das leis mais importantes da República e dos princípios sociais e democráticos atinentes ao desenvolvimento do espírito cívico, mediante palestras ou conferências públicas". A União Republicana refere que, entre os seus propósitos, quer "Manter e assegurar a neutralidade da Escola, arredando todo o espírito sectarista, não deixando que ela se converta em instrumento de propaganda a favor ou contra qualquer religião" e "Promover a rigorosa execução da lei que torna obrigatório o ensino primário elementar, menos por via coerciva do que pela adoção de providências que tornem fácil aos pobres mandarem os filhos à Escola". O Partido Republicano Evolucionista diz que "considera como fundamental para o futuro engrandecimento do País a instrução em todos os seus ramos e a educação cívica de todos os portugueses" e para alcançar estes fins, concretamente quanto ao ensino primário, afirma que é pela "execução do Decreto com força de Lei de 29 de Março de 1911 do Governo Provisório da República”. Quando se aproxima do "Problema Religioso" esclarece que é favorável à "Revisão da Lei de Separação das Igrejas do Estado no sentido de a harmonizar com a Constituição, ressalvando os princípios desta, introduzindo-lhe as modificações necessárias para assegurar a paz religiosa", de acordo com um princípio: "Igualdade política e civil de todos os cultos, sem sustento ou subsídio por parte do Estado", o que necessariamente implica "em matéria de ensino, harmonizar a Lei da Separação com a Constituição".

A Lei de Separação do Estado das Igrejas é o expoente da radicalização das posições republicanas. A velocidade legislativa não se 
compadecia com as condições sociológicas da sociedade portuguesa, nem também com as idiossincrasias que povoavam o universo republicano. Por um lado, verifica-se, que em termos gerais, a República visava pôr fim ao ensino religioso na escola portuguesa e introduzir um novo sistema de educação que valorizasse os princípios laicos, que eram almejados para a sociedade portuguesa, reflectidos na doutrinação de uma nova ética (imanente e social, como enfatiza Fernando Catroga) e num novo ideal de educação cívica, que teria como pilar da sua disseminação o professor - declinado como "mensageiro da ilustração", "soldado do progresso", "sacerdote da religião educativa" ou "cultor da razão", entre muitas outras metáforas - e o local por excelência da sua difusão o "santuário da escola". A educação surgia com emancipação do povo e veículo por excelência capaz de promover o ressurgimento nacional, como defendia António Sérgio (1915). Note-se que a pluralidade de perspectivas que presidia à significação da escola pública republicana passava pela sua democraticidade (Bernardino Machado), pela cientificidade do processo educativo (Adolfo Coelho) e pela laicização da escola (João de Barros) tendo em vista formar o "homem novo": "Ensina-se o respeito por todas as opiniões religiosas, a tolerância - a liberdade de consciência, enfim; mas, ao mesmo tempo, inspira-se essa educação nas descobertas da ciência, nas conquistas, no desenvolvimento e no progresso da inteligência humana." (Barros, 1914, p. 25). Por outro lado, assiste-se em simultâneo, à emergência de vozes republicanas descontentes com a crispação originada pela Lei da Separação, que se patenteiam com toda a sua virulência nos debates da Constituinte, emergindo posições contrastantes: uns defendem "uma educação religiosa em bases verdadeiramente neutras" e outros são apologistas que "a República deve provar que o ensino leigo é de facto neutro em matéria religiosa", quer nos "estabelecimentos públicos", quer nos "estabelecimentos de ensino particulares fiscalizados pelo Estado". No debate não deixam de surgir indicações que outros modelos poderiam ser possíveis (como os brasileiro, italiano, belga, inglês ou norte-americano) que evitassem as rupturas sociais e promovessem o compromisso entre o Estado e a Igreja - estão neste aspecto consideradas as propostas de Eduardo de Abreu ou de Basílio Teles. "Os debates ocorridos em 1914 trazem à consideração a explicitação da recomposição política e religiosa 
que o decreto veio acelerar, procurando colocar o Estado como protagonista da dinâmica de secularização pelo erguer de um projecto de laicização das estruturas políticas e do enquadramento simbólico da actividade dos cidadãos" (Pinto, 2008, p. 72).

O multimodo de entender o estatuto da educação moral fica patente nas críticas de Leonardo Coimbra ou de António Sérgio, o que denota que na área republicana se estava atento à emergência das cidadanias resultantes da reconfiguração das sociabilidades religiosas, bem assim como uma leitura da modernidade assente na harmonização (ou compromisso) entre o Estado e as Igrejas, para além de um entendimento do papel cultural do religioso, bem distinto da militância republicana radical. Aliás, a outros níveis, também se detecta que o projecto laicizador dos republicanos é bem mais vasto que a "questão educativa", mas paradoxalmente a ela se reduz. Os debates em sede parlamentar induzem esta constatação e ilustramse nas questões que vão desde o jogo até à lei eleitoral - com inúmeras contradições e retrocessos no que se refere à implementação do sufrágio universal -, passando pela "questão agrícola" e pelo funcionalismo de Estado - entendido como correspondendo às novas missões do Estado e que tem implícita uma moral republicana de serviço público, tendo sempre como pressuposto que ser republicano implica uma aprendizagem que se adquire desde a escola, mas que indelevelmente se deve pôr em prática em todos os actos da vida quotidiana. Mas esses mesmos debates deixam transparecer que os constrangimentos que pairam sobre a jovem República podem ser razões que façam soçobrar os projectos. Entre os argumentos mais ponderosos os de natureza económica são os mais determinantes. Háos também de ordem ideológica como ainda os de natureza política.

A sociedade portuguesa está vulnerabilizada e a "escola republicana é ridicularizada pelos reaccionários" - como se expressa com mágoa um parlamentar em 1913 - e a "reacção clerical" é de uma pertinácia inexcedível". O Relatório do Governo Apresentado às Câmaras Legislativas em 2 de Dezembro de 1913 é elucidativo quanto à identificação da violação da "neutralidade do ensino em matéria religiosa". Consta no documento que se assistia a violações da lei em alguns colégios particulares e, também, por parte de professores oficiais, esclarecendo que medidas seriam tomadas: "Todos os colégios particulares em que se façam práticas 
religiosas serão encerrados, todos os professores oficiais, que infringirem as leis nesta matéria, não esperem outro procedimento do Governo que não seja decretar-lhes a demissão". Diz-se também no Relatório... que não servirá de desculpa dizer-se, no caso dos colégios particulares, que não há ensino religioso mas sim educação religiosa porque "as famílias dos alunos desejam a educação religiosa", e, no caso do ensino público, não será "admitida qualquer explicação" e "nenhuma desculpa será recebida sequer". No mesmo documento é elencado um outro ataque à República, por parte do "funcionalismo da instrução": "é a rebelião monárquica em que se lançaram certos professores; perante um tal acto, uma vez provado, também o Governo não tomará outra medida aquém da demissão". Neste Relatório fica patente que a escola pública está fragilizada no seu propósito de laicidade - em 1916, João de Barros, num exercício retrospectivo profere uma sibilina afirmação: "Quase toda a obra pedagógica da República tem sido - como dizer? - exterior. Não buliu ainda no espírito do ensino - buliu apenas na sua aparência" (Barros, 1916, p. 25).

Um outro documento referente às Escolas Móveis (iniciadas em 1913) é ilustrativo de um certo estado da educação. Assim, no relatório sobre o funcionamento dessas Escolas nos anos 1913-1914 e 1914-1915, designado por Escolas Móveis - Relatório do Inspector, é dito que existe uma percentagem grande de analfabetos nas povoações urbanas, mas nas zonas rurais "a percentagem chega a ser verdadeiramente aterradora nesses milhares de povoados disseminados por todas as zonas do país". O Inspector esclarece que "a maior parte das nossas freguesias rurais é constituída por núcleos de população, sem vias de comunicação que os liguem à sede das freguesias, e delas afastados seis, oito, dez e mais quilómetros", e diz, com veemência, que o único meio de levar a civilização a esses locais é a escola, porque para além de combaterem o "atraso mental dos nossos aldeões" possibilitarão que as aldeias "bendigam o 5 de Outubro". O seu parecer vai no sentido de enfatizar que as Escolas Móveis têm um bom "acolhimento na alma popular". Diz-nos também que elas são o veículo de "republicanização das aldeias", significando com esta afirmação que, por um lado, o espaço rural ainda estava distanciado da República e, por outro lado, que a influência das forças reaccionárias era uma realidade que, com urgência, deveria ser combatida, e a via de levar as classes populares rurais ao "convívio do mundo culto" seria erradicar o analfabetismo. Ao professor 
estava-lhe então adstrita uma "missão patriótica" e aqueles que não a compreenderam não foram, segundo afirma o Inspector, reconduzidos.

Estes dois documentos são significativos sobre a tensão que a escola pública laica tinha em se afirmar, seja pelas resistências inevitáveis que este modelo levantava (Carvalho, 2011; Matos, 2011) - é por isso que frequentemente em documentação oficial se refere o "professor pacificador" -, seja porque os próprios professores ainda não estariam prontos para serem os "sacerdotes laicos". O que nesta conjuntura estava em questão é que a escola é por excelência um instrumento de um ideal de educação e que as políticas educativas são o resultado não só dos grandes objectivos ideológicos como também das pequenas decisões dos actores. Compaginar estas dinâmicas num Estado não confessional era o desafio que se colocava para que a "revolução cultural", na expressão de Fernando Catroga, tivesse sucesso num país que recentemente tinha estilhaçado o multissecular predomínio no espaço público da religião católica. Neste sentido também são nítidas as distintas preocupações táticas. Vidal Ondinot (1915) num texto bastante apelativo, mas extremamente prudente, tece uma incisiva defesa da escola laica - enquanto locus de cidadania no quadro da socialização para a res-publica - via as dinâmicas pedagógicas que introduz e fomenta. Não evita, contudo, de criticar a neutralidade tímida da escola. Posição análoga é defendida também por Lúcio Pinheiro dos Santos (Baptista, 2010), entre muitíssimas outras vozes, cujo registo tende, essencialmente, a privilegiar a obra (como frequentemente os republicanos insistiam em afirmar) como exemplo de atração das populações. Nota-se, no entanto, a firmeza de posições mais aguerridas na defesa de uma escola rigorosamente laica, destacando-se pela sua persistência Tomás da Fonseca (Torgal, 2012), em nítido confronto com correligionários democráticos, e maçónicos.

\section{O mosaico republicano}

Aconjunturamarcada pelo conflito bélico teve enormes repercussões no país, originando drásticas restrições no quadro da República social que foi esboçada nos primeiros anos após o 5 de outubro. As relações políticas estavam crispadas e a reação católica à Lei da Separação era forte, apesar 
das tentativas pacificadoras surgidas em 1912 e 1915 (Marçal, 2010) no contexto do modus vivendi constitucional. As representações que as forças políticas, nomeadamente, as conotadas com a oposição, veiculavam, tendiam a identificar o Partido Democrático como o responsável pelo caos, a anarquia e a desorganização que o país patenteava. Impunha-se, portanto, uma solução política que regulasse e estabilizasse, em definitivo, a República. As forças políticas conservadoras sentiam-se galvanizadas pelo fenómeno das aparições de Fátima e no campo republicano surgiu uma liderança de contornos presidencialistas, tida como "salvação pública" (Cunha e Costa, 1921, p. 21). Sidónio Pais encarnou essa messiânica esperança. As eleições de 1918 foram a oportunidade da formação partidária liderada pelo General - Partido Nacional Republicano. A proposta que apresentou ao eleitorado enfatizava o almejado restabelecimento das relações entre Portugal e o Vaticano e pretendia concretizar reivindicações católicas: a possibilidade do ensino religioso nas escolas particulares. $\mathrm{O}$ projeto político de Sidónio Pais era certamente bem mais amplo, mantendo, contudo, o quadro da Separação do Estado das Igrejas. A "interrupção do código genético do Estado parlamentar" (Matos, 2010, pp. 38 sq.) reside precisamente em que o sidonismo configurava o presidencialismo, ainda que modelado por um conjunto de dispositivos jurídicos de recorte republicano. No campo republicano há recomposições partidárias interessantes. O Partido Centrista (fruto de uma cisão, em outubro de 1917, do Partido Evolucionista) dissolve-se e esboça-se a criação do Partido Nacional Republicano, liderado por Egas Moniz. A República Nova é veloz, mas efémera. $\mathrm{O}$ assassinato de Sidónio Pais coloca um fim trágico a essa experiência ditatorial que lançou as "bases da reconciliação entre Deus e César" (Cunha e Costa, 1921, p. 51). Note-se que as eleições de 1918 registaram uma significativa votação no Partido Nacional Republicano $(69,7 \%)$, tendo as forças católicas obtido $3,2 \%$ e as monárquicas (que se apresentaram pela primeira vez a sufrágio) alcançado os $23,9 \%$.

No programa do Partido Centrista Republicano, constava o seguinte: "Em matéria religiosa, assegurada pela legislação a supremacia do poder civil, garantida a liberdade de cultos, mantido o regime de separação do Estado e das Igrejas, é concedido ao padre secular o gozo de todas as regalias de cidadão português, julgamos indispensável reatar 
as nossas relações diplomáticas com o Vaticano, celebrando, por assim dizer, a Concordata da Separação, como meio de tranquilizar os espíritos e pacificar as consciências".

Alastra paulatinamente no campo republicano, um conjunto de posições que consistentemente corporizam o resfriar de algumas das mais radicais manifestações laicizantes e, porventura, intolerantes.

O reorganizar do ciclo parlamentar faz-se naturalmente por motu proprio e as eleições em 1919 são expressão dessa viragem constitucional, significando também que a disputa política se fará num contexto de clarificação do campo republicano e marcado pela real politik, muito especificamente no reatar de medidas que tendam a criar a almejada República social e centradas no "saneamento dos problemas sociais e económico-financeiros do pós-guerra" (Pinto, 2011, p. 56 sq.). Significa a fixação modernizadora que a instabilidade do campo republicano, especificamente naquelas formações partidárias de matriz constitucional, se irá manter com dissidências, cisões e fusões, e como sublinha Ana Catarina Pinto: "Podemos sintetizar a reorganização partidária da República em três traços, do lado conservador a união de forças, do lado radical a criação de novos agrupamentos - o que indicia o facto dos partidos da 'República Velha' não estarem aptos a fazer a apropriação do programa radical do país pós-guerra -, ao centro o esvaziamento, indicado pelas cisões à esquerda e à direita no seio do PRP. São três sintomas da polarização política que caracterizou os anos de 1919 a 1926” (id., p. 47), mas tal não significa que a turbulência se tenha desvanecido nem que a crispação política tenha desaparecido - há um conjunto de sinais que indiciam que os monárquicos reagiram com determinação (a designada 'Monarquia do Norte', de 3 de Janeiro a 13 de Fevereiro de 1919) ou que os sectores republicanos mais radicais não assumissem as novas condições de consenso necessário que a realidade política exigia (vide a 'Noite Sangrenta', de 19 de Outubro de 1920) - apesar da assunção explícita, no campo republicano, da urgência das reformas sociais, que indelevelmente recuperariam a justiça numa sociedade dilacerada e assimétrica.

Assim, em 1919, as formações republicanas mais votadas foram o Partido Democrático (52,8\%), o Partido Evolucionista (23,3\%) e o Partido Unionista (10,4\%); os monárquicos não se apresentaram a escrutínio e os 
católicos obtiveram $0,6 \%$. Os três partidos mais votados replicaram as suas propostas de 1915. Surgem, contudo, outras expressões, nomeadamente as do Partido Republicano Conservador, uma formação neo-sidonista, que propunha no capítulo das 'Relações da Igreja com o Estado' manter “em matéria religiosa o status quo, reservando para negociações diretas com a Cúria Romana, quaisquer alterações que seja necessário introduzir na legislação vigente que regula as relações de respeito mútuo entre Igreja Católica e a República Portuguesa”, já no que respeita ao 'Ensino' diz, muito laconicamente, que "no ensino profissional e geral, pouco poderá subsistir do que se tem legislado e reformado, quase tudo, senão tudo por fazer"; as do Partido Republicano Liberal que insiste que na 'Instrução pública' é "necessário, para bem da República, que o ensino não só se estenda a todos, mas se intensifique e se aperfeiçoe, de modo a colocar a elite intelectual do país em nível igual ao que ela atinge nas nações de mais perfeita civilização", propondo uma "revisão da Lei da Separação" com base nos seguintes argumentos: "Em matéria de religião [o PRL] entende que deve manter-se a separação entre as igrejas e o Estado; e embora a lei que estabelece esteja hoje modificada no sentido de se lhe tirar o carácter agressivo para a consciência religiosa, pensa que há razão ainda para ser feita a sua revisão, por forma que ela se harmonize inteiramente, com a lei fundamental da República e dela ressalte a tolerância e o respeito pelas crenças de todos os portugueses e pelas legítimas liberdades das igrejas (...) e consignando a necessidade de assegurar a neutralidade da Escola, não permitirá que esta se converta em instrumento de propaganda a favor ou contra qualquer religião", e a União Republicana (in A Luta, 3 Maio 1919 , p. 1) que propõe "a organização política das classes conservadoras para que não se rompa brutalmente o equilíbrio social e o sonho de uma igualdade perfeita", esclarecendo que "a educação, tomada a palavra no seu mais largo significado, é um elemento de transformação social mais poderoso que as leis; mas não é eficaz à maneira de certos remédios que atuam assim que se tomam, antes carece de tempo para atuar eficazmente", é com base nesta preposição que constantemente referem que é a razão que deve mover as "classes conservadoras" - conotados como "bons cidadãos, trabalhadores honestos e pacíficos" - na senda da Ordem, da Liberdade e da Autoridade - categorias que permitem a identificação do "regime 
com a sociedade" -, como consequência a União Republicana - "partido conservador, segundo o critério positivo, científico, modernamente adaptado ao estudo da resolução dos problemas sociais" - reclama: "garantias eficazes para o exercício de todos os direitos", "repressão ou castigo de todos os abusos" e "melhorar as condições das chamadas classes trabalhadoras" mas "sem implicar espoliações".

Em 1921, o Partido Liberal obtém 48,5\% enquanto o Partido Democrático ficou pelos 33,1\%, surge o Partido Reconstituinte com 7,4\% - o Partido Evolucionista e o Partido Unionista eclipsaram-se - e as forças católica e monárquica obtiveram, respetivamente, $1,8 \%$ e 2,4\%. Configurouse neste ato eleitoral uma viragem à direita no campo republicano.

O Partido Republicano Liberal (in República, 23 Junho 1921, p. 1) propõe "face à situação económica e financeira gravíssima" um conjunto de sete "providências" para "a profunda remodelação" da sociedade, reiterando os apelos para o "cumprimento do mais sagrado dos (...) direitos do cidadão, contra a abstenção eleitoral” (in Folha volante, 1921) porque dos eleitores depende o "não regressar à política anterior", avalisando, portanto, "a política de ordem, de trabalho, de tolerância e de liberdade" e, por extensão, da "honorabilidade e da competência". O seu programa, como já referimos, é inequívoco quanto à Lei da Separação.

O Partido Democrático, que se apresenta, em Lisboa, como Partido Republicano Português (in Folha volante, 1921), reclama, sem qualquer receio, a herança do "velho e honrado Partido Republicano Português" esclarecendo que é o partido que "proclamou a República e que mais tem lutado e sofrido pela sua conservação" - e as "aspirações dos verdadeiros republicanos e patriotas". O manifesto esclarece os propósitos políticos, nomeadamente, "a moralização dos serviços públicos e o equilíbrio orçamental", a "promulgação de medidas sociais em benefício das classes mais desvalidas de harmonia com os preceitos de justiça e humanidade", em simultâneo com o "fomentar o desenvolvimento económico do país e das colónias", sem jamais olvidar "pugnar pela manutenção das conquistas liberais, refreando os assomos da reação clerical, sem prejuízo do respeito que deve a todas as crenças sinceras".

O Partido Reconstituinte (in O Século, 22 Junho 1921, p. 1-2) refere no seu programa "a defesa da independência nacional e a salvaguarda 
da República, considerando esta como o único instrumento possível de emancipação moral e material da democracia e do programa da pátria portuguesa". Declara-se defensora do regime parlamentar, contra qualquer manifestação "de poder pessoal e arbitrário" e adversária de "golpes de Estado"; é a favor da "supremacia do poder civil" e regionalista, advogando a "economia dos municípios" e a "descentralização administrativa". Pugna por uma "profunda modificação na organização da administração" e reivindica o "princípio da propriedade individual" em simultâneo com a "formação e desenvolvimento de sindicatos e associações cooperativas [encorajando] todas as instituições pelas quais o proletariado possa valer os seus direitos, defender os seus interesses, melhorar a sua situação moral e material, obter a legítima remuneração do seu labor", é, em suma, a favor da "liberdade de trabalho" e declara "combater os extremismos", por meio da união das "tendências de moderação e de tolerância", dentro "da moralidade, da disciplina e da lei" e na convicção de que "a alma de um povo livre não pode deixar de acompanhar os que querem salvar a sua Pátria e dignificar o regime republicano, pelo culto sincero das virtudes cívicas e morais".

O Partido Nacional Republicano Presidencialista, no seu manifesto declara que "no respeitante à questão religiosa" defende que "o princípio da separação é o único assegurador de igualdade política e civil de todos os cultos, doutrina esta que a uma Democracia pertence sustentar, mas reconhecendo que de todas as religiões professadas pelo País, é a católica a que reúne a grande massa dos crentes, que é também a grande maioria dos portugueses", pelo que advoga inequivocamente a "conservação e o maior estreitamento de relações com a Santa Sé como melhor garantia do respeito mútuo entre a Igreja e a República" e a "satisfação das principais reivindicações da consciência católica que são: o reconhecimento da hierarquia religiosa, o exercício da autoridade da Igreja sobre o culto e a liberdade do ensino religioso nas escolas particulares". O Partido assume-se como "uma pequena minoria, mas nela residirá a mais segura garantia de uma fiscalização intemerata, assídua e patriótica dos trabalhos parlamentares" (in Folha volante, 1921), assegurando o combate aos "interesses das clientelas partidárias que normalmente têm detido o poder", e, por consequência, a "desordem demagógica" e os "ataques até aqui permanentes às liberdades e garantias individuais de cada cidadão", 
assegurando enfim - em homenagem à "sagrada memória” de Sidónio Pais - que a "sua política, intransigentemente republicana, será conservadora, respeitando os mútuos direitos da propriedade e do trabalho, mantendo a tradição religiosa nacional [com] as garantias a que tem direito", o que na sua linguagem partidária quer significar uma "política de paz e de concórdia". Neste sentido, o programa do deputado Gomes Mota (in $O$ Século, 5 Julho 1921, pp. 1-2) explicita que os "princípios preconizados pela Nova Democracia" vão no sentido de uma "reforma essencial da Constituição" e de "acabar com o Parlamento Ditador" - propondo substituir "a representação meramente política" por uma "representação profissional de todas as classes, unidas com competência para delegar a atribuição de legislar sobre interesses próprios ou interdependentes" -, para além, esclarece, de permitir "o desenvolvimento do espírito sindical em marcha, tirando-o da forma revolucionária e do campo ilegal em que vive", através de um "projeto de lei sobre associações de classe".

Em "matériareligiosa",odeputado propõea "defesa, desassombrada, da necessidade de cultivar e manter os preceitos do cristianismo" através, diz, do "reconhecimento da Igreja católica, como sendo a consagrada pela nossa tradição histórica e, por excelência, a própria das convicções da quase totalidade de todos os portugueses para o ensino e ministração destes preceitos úteis". Logicamente configura o "estreitamento maior das relações do Estado com as da Santa Sé" e a "satisfação das principais reivindicações católicas e o restabelecimento das missões religiosas no Ultramar".

O Partido Republicano Popular, em contrapartida, afirma taxativamente "combater o clericalismo e respeitar as crenças íntimas de todo o cidadão". A Federação Nacional Republicana - subordinada ao "lema reformista": "Ordem e Trabalho, Tolerância e Progresso" - pretende aliar "os princípios democráticos ao sentimento de tradição nacional e dar coesão à raça".

Nas eleições de 1922, o Partido Democrático obtém 45,4\% dos votos, o Partido Liberal 20,9\% e o Partido Reconstituinte 10,3\%, os monárquicos chegam aos $7,9 \%$ e os católicos aos $3,1 \%$ (resultado idêntico àquele que obtiveram nas eleições de 1918, onde nenhuma formação constitucional republicana se apresentou ao sufrágio). A este escrutínio apresentou-se uma lista de Conjunção Republicana, com o objetivo de 
congregar "os republicanos que não estão filiados no partido democrático", e propondo alianças com os socialistas, afim de ultrapassar "dissidências partidárias" e "ressentimentos políticos". No plano político, a campanha dirige-se contra os monárquicos, apelando à urgência em "reerguer no plano popular a fé republicana de outros tempos" sublinhando que a República foi "um protesto de reação moral" eivado por um "forte idealismo e uma fé superior" mas também esclarecendo que não "pretende combater o partido histórico da República [obviamente o PRP] " porque se por tal via enveredassem, estariam "em contradição com o próprio fundamento que lhe deu origem" - para "suprir o que nos falta e valorizar a ação comum nacional" (in A Vitória, 26 Janeiro 1922, p. 1 e A Luta, 26 Janeiro 1922, p. $1)^{5}$. O Partido Republicano Português (in Cartaz, 1922) propõe-se com uma lista de candidatos conhecidos pela sua "honradez" e como "defensores de uma classe menos protegida", combater o "passado tenebroso" e pugnar pelos "princípios da Democracia".

O Partido Republicano de Reconstituição Nacional afirma no seu programa a crença na "tolerância política e na liberdade" porque é um partido "intransigentemente afeto ao regime implantado no 5 de Outubro de 1910" que considera inequivocamente "Portugal e a República duas designações para sempre destinadas à mesma e indivisível ideia de Pátria". Esclarece, contudo, que defende o princípio de que a "tolerância não colide com a rigidez das crenças, mas uma e outra se condicionam e congraçam", atendendo às "circunstâncias da hodierna política portuguesa". Tais princípios ("tolerância política e religiosa") são obviamente extensíveis em "matéria de ensino e educação nacional".

O Movimento de "19 de Outubro de 1921" proclama com extrema radicalidade que se deverá "por especial cuidado em restaurar na sua pureza primitiva as leis basilares da República, sobretudo a da separação do Estado

\footnotetext{
5 Retenha-se um exemplo da propaganda monárquica (in Correio da Manhã, 27 Janeiro 1922, p. 1) em que se enfatiza que os "onze anos de república" fomentaram as "doutrinas dissolventes" e o "anarquismo" e que a Lei de Separação conduziu a um crescendo de "arbitrariedades", "perseguições violentas" e "baniu das escolas a educação moral e religiosa". O apelo aos eleitores é que recordem esses anos porque estão presentes na "vossa memória", reforçam enfaticamente os monárquicos - associando-os às "duas poderosas reações" [Pimenta de Castro e Sidónio Pais] para catapultarem para o Parlamento uma força política que "deixou o país com dignidade".
} 
das igrejas, dando o mais rigoroso cumprimento às leis anti congreganistas de Pombal, de Aguiar e da República, e em revogar e suprir todas as que, sob a própria égide da República, contra elas foram promulgadas". Na linha do neosidonismo, o Nacionalismo Lusitano lança um substantivo programa em que está patente o axioma que um "dos cuidados do nacionalismo [é] a proteção à religião tradicional e a defesa contra outra religião estranha ou nova"; continua: "Para tal conseguir é que se organiza a Religião Tradicional dentro do Estado para que mutuamente se amparem o espírito nacional e o espírito religioso [que significa: "espírito católico"]", naturalmente dentro de "uma base" (como o redator a nomeia) em que há "uma religião de Estado com regime privilegiado e meios de defesa dentro da lei contra a expressão de outras religiões". O corolário - em termos práticos, significa a extensão de uma política de "moralização" (em todos os níveis da sociedade) capaz de promover a "reconstrução nacional". A sua tradução no âmbito da Instrução será a promulgação de uma Lei Geral de Instrução, com "carácter nacional obrigatório", em que, para além da organização dos estudos nos vários ciclos, se estipulará que "será proibido terminantemente todo e qualquer ensino antipatriótico e antinacional". O âmago de todas as leis é a renovação "da tradicional organização familiar e a sua indissolubilidade e autoridade".

As eleições de 1925 revelam que o Partido Democrático (ou como já vinha sendo apresentado: Partido Republicano Português) obteve $50,9 \%$ dos votos, o Partido Nacionalista situa-se nos 22,1\%, a Esquerda Democrática 3,7\%, os católicos 2,4\% e os monárquicos 4,3\%.

A Esquerda Democrática (in Cartaz, 1925) denuncia com veemência o "vergonhoso hibridismo de República e Monarquia" que se ia disseminando com contornos preocupantes, compreendendo-se o apelo no "reforço e implementação do Estado Social" - no qual configuram "uma reforma da educação nacional que dê unidade, harmonia e fecundidade aos espíritos pela compreensão dos nossos destinos históricos e pela valorização efetiva e próspera dos nossos patrimónios" - como meio de recusa do dilema "entre dois formalismos políticos - República ou Monarquia", e como via de contrariar "todas as reações e oligarquias" favorecendo "a Democracia e a Nação". Em síntese, o manifesto é uma apologia da "Democracia republicana". 
O Partido Republicano Português (in O Mundo, 17 Outubro 1925, p. 1-2) apela a que "acima das divergências de confissões religiosas, muito acima dos interesses de ordem individual ou regional, está o culto da Pátria, o destino do povo português" e recorda - com uma evocação à "memória dos que morreram" - que a República é o "regime de conciliação entre todos os portugueses patriotas e desinteressados". Uma nota histórica remete para o período da dissolução da Monarquia e evoca os primeiros seis meses da República, em que a "reação assanhada" justificou as medidas do "governo provisório". Num parágrafo afirma-se: "Ora a chamada questão religiosa deve ser considerada apenas sob o aspeto jurídico das relações entre o Estado e a Igreja", esclarecendo que "Quanto ao mais, a República mantém-se neutral, respeitando e assegurando o exercício de todos os cultos, e não discutindo as crenças dos indivíduos nem os perseguindo ou vexando por motivos de religião, porque as crenças religiosas são do domínio de cada um e a liberdade de consciência é inviolável"; o texto conclui que: "Professar ou deixar de professar uma religião em caso algum pode ser motivo para adquirir ou perder direitos civis e políticos, inerentes à qualidade de cidadão português". Este enfatizar do espírito da Constituição é acompanhado por um conjunto de medidas económicas, sociais e financeiras.

O Partido Republicano Nacionalista (in Democracia do Sul, 3 Novembro 1925, pp. 1-2) começa o seu manifesto afirmando que "A crise moral que atravessamos, e que se carateriza pela descoordenação de todas as energias nacionais, pela carência de um ideal coletivo e pela falta de unidade moral da Nação (...)" tem que ser contrariada por uma "força construtiva e ordeira" que promova o "regresso ao culto das virtudes cívicas que constituem o esteio moral de todas as democracias" e evite a "decadência das instituições parlamentares". Num quadro constitucional - de que o Partido Republicano Nacionalista se reclama - é indispensável "fortalecer o poder civil" e "tornar efetiva a liberdade das religiões especialmente da religião católica, que é a maioria dos portugueses, de forma que, mantendo-se rigorosamente a neutralidade do Estado laico, seja livremente permitido o ensino religioso nas escolas particulares". São tecidas considerações sobre o operariado e reforça-se a ideia - que tinha sido explícita no Programa de 1924, nomeadamente no capítulo 
"Política pedagógica" - de que a "educação popular" deve ser promovida em "extensão e intensidade", porque é a "base das democracias modernas" e "necessária [para] a formação das elites". O manifesto encerra com o sublinhar da novidade que o Partido representa quanto ao espírito, ideias, processos e moral política, mas também da sua proposta: ordem (vs. desordem), legalidade (vs. arbítrio), paz civil (vs. ameaça revolucionária) e autoridade ( $v s$. anarquia).

Em documento surgido em 1923, o Partido Republicano Nacionalista, propunha-se "receber os elementos ativos que constituem os partidos dissolvidos, mas também, e muito principalmente, restituir à República os valores que ela perdeu, e integrar no regime aquela massa neutra e flutuante da nação, que não sendo monárquica e não se adaptando facilmente a qualquer fação republicana radical, espera apenas, para entrar na atividade política, que se organize, dentro do regime, um sólido partido de governo, representativo das correntes moderadas da opinião republicana". Claramente assumia-se como da direita republicana, conservador, constitucionalista, nacionalista, tolerante, pacificador, respeitador das tradições nacionais, pela Pátria e pretendendo "completar a obra da nacionalização da República, que não é apenas um regime para os republicanos, mas um regime onde cabem todos os portugueses".

O Partido Republicano Radical, no capítulo "A República perante as igrejas" do seu Programa, declara que "A República garante, a todas as religiões, a mais ampla liberdade de culto, não mantendo relações oficiais com qualquer delas"; que é apologista da "Manutenção da lei de separação no seu espírito e orientação" - implicando a "Extinção da legação junto ao Vaticano" -, e que é defensor da "Proibição absoluta do ensino sectário nas escolas oficiais ou particulares". O Programa contempla um capítulo sobre "Reformas morais e intelectuais", onde entre as muitas medidas propostas se vinca a necessidade de um Código da Instrução e as quatro bases [Intelectual, Física, Moral e Cívica] imprescindíveis para a "Remodelação da mentalidade e do carácter português". O Partido assume uma "orientação democrática e social" e defende a transformação das "instituições republicanas num instrumento de solidariedade social".

O Partido Radical (in O Directorio do Partido Radical..., 1925) intitula-se como "herdeiro legítimo da profunda emoção que há vinte 
anos agitou o país, na esperança de uma República que fosse o resgate de oitenta anos de constitucionalismo outorgado e outros tantos de tripudio dos partidos da monarquia sobre a nação", propondo-se denunciar "vícios e desvios" e contrariar a "falta de relação entre os chamados partidos políticos e os interesses nacionais", através de "propaganda junto do povo" para que adquira novamente interesse pela "marcha das coisas públicas". Tece críticas ao Partido Nacionalista, ao "grupo neutralmente rotulado por Ação Republicana", ao Partido Democrático - destacando o facto de se ter transformado no partido da "mais parasitária clientela do regime", "fechando-se agressivamente a quantos não comungassem nas suas tábuas da lei, e procurando destruir todas as forças que pudessem fazer-lhe sombra ou perturbar-lhe a digestão" -, à esquerda democrática e ao personalismo. O seu Programa contempla um conjunto de soluções para os problemas político, económico, social - onde destaca a questão escolar, particularmente pela imediata criação de escolas técnicas regionais, ações de trabalho e os bairros sociais - e indígena; refere soluções transitórias, umas de índole económico-financeira e outras políticas, como a pacificação nacional e o "estabelecimento [de] uma moral democrática".

O Núcleo Republicano Reformador é um "movimento de salvação pública" que reage contra a "obra sistemática de falsificação do ideal republicano e de menosprezo pelos interesses do país". Relativamente à "questão de instrução e de educação", pretende dar "ao ensino uma feição prática, segundo as aptidões individuais e as necessidades e recursos materiais e morais do país", não esquece o "dignificar as funções do professor", já no que se refere à "questão religiosa" quer "estabelecer o regime de completa separação nas relações do Estado com a Igreja; permitir o livre exercício de cultos, salvas as restrições das leis de Pombal e Aguiar, podendo o Estado ceder à Igreja o usufruto dos bens necessários ao culto, mas subordinar a uma rigorosa fiscalização todos os estabelecimentos dela dependentes e assegurar junto da mesma a defesa de quaisquer interesses materiais ou de ordem social".

6 Formação essencialmente parlamentar resultante de uma dissidência no Partido Republicano Nacionalista (Leal, 2008, p. 105 e 319-320). 
O ciclo político de 1919 a 1926 é marcado pela intervenção no plano social (Pereira, 2011) em simultâneo com a crescente organização sindical e o correlativo poder reivindicativo (Ventura, 2010), é, ainda, um tempo caraterizado por uma afirmação da esquerda republicana: "Enquanto o campo conservador convergiu para a ideia ditatorial, antiliberal e antiparlamentarista, do lado radical o pensamento reformista deixou de se cingir a medidas conjunturais, assumiu um ideal de justiça social e encontrou coerência suficiente para delinear um projeto de remodelação democrática da República" (Pinto, 2011, p. 71). A tradução desta política radica no abrandamento de tensões estruturais caraterísticas da instauração da República, onde, certamente, se incluíam as relações com a Igreja Católica, nos anos 1922 e 1923, relativamente à questão do ensino religioso (Matos, 2011, p. 495-667, especialmente, pp. 568-570). Apesar do tendencial clima de aproximação, esta posição não deixou de provocar episódios dramáticos, como sejam o da demissão do Ministro da Instrução, o democrático Leonardo Coimbra, por ter proposto que o ensino religioso "passe a ser livre nas escolas particulares fiscalizadas pelo Estado" (Fava, 2008, pp. 107 sq.). Outros houve que patenteavam que a ortodoxia laicista, ainda persistia entre os republicanos, apesar de ser um laicismo "verbal, minoritário e mais influente no Estado do que na organização social" (Matos, 2011, p. 613). No entanto, tal decorrer da política nacional não impediu que um golpe de Estado, a 26 de Maio de 1926, colocasse um ponto final na atribulada - mas necessária, dizemos nós, como aprendizagem do viver em democracia - experiência inaugurada em 1910.

Em 1926, coexistiam seis formações saídas do Partido Republicano Português, à esquerda: Partido Radical, Esquerda Democrática e Partido Democrático (ou Republicano), e à direita: Ação Republicana, Partido Nacionalista e União Liberal.

As posições políticas estavam relativamente definidas. Do lado da União Liberal Republicana afirmava-se que se procurava "transformar as escolas em instrumentos de formação do carácter e de educação cívica, conseguindo assim pela valorização consequente da célula social atacar, na origem, os males que nos afligem e que, aliás, por uma espécie de neurastenia coletiva, frequentemente exageramos". O Manifesto, reafirma que "a formação do carácter e do patriotismo pela Escola, a partir da 
primária, cuja obrigatoriedade de frequência é necessário efetivar, e o desenvolvimento progressivo de ensino, subordinados ao reatamento da tradição nacional, sob todas as formas compatíveis com as normas da Democracia”, completando-se este princípio com “A legítima preocupação do respeito pela Tradição e o sereno exame das realidades impõe-nos, em matéria religiosa, que se dê satisfação às aspirações legítimas da consciência católica", porque, em síntese, sublinham: "É absurdo que nos esqueçamos que vivemos num país de católicos, que têm direito, como portugueses, a que a sua fé considerada com simpatia pelo Estado, e não sistematicamente hostilizada".

A Esquerda Democrática reivindica sem qualquer restrição o programa republicano de 1891, esclarecendo que "A Democracia tem um fundamento filosófico e uma base moral" pelo que reconhece "todas as liberdades individuais", e a "dignidade humana" - sublinhando que ela é "sobretudo o produto da educação", pelo que à "igualdade perante a instrução" se deve acoplar a "igualdade perante a educação". Pretendem uma "democracia mais pura" e uma República organizada em "moldes republicanos", afirmando, com convicção, que pretendem impedir que a "descrença se não estenda até à própria República", através do reforço da República Social como pelo tornar efetivos alguns dos dispositivos democráticos, como o sufrágio universal, "sem exclusão da mulher, pelo menos, da mulher diplomada", entre outros. Numa substantiva tese apresentada ao Congresso da Esquerda Democrática, Leonardo Coimbra (1926), defende, sem qualquer receio, que "educar é cultivar as liberdades criadoras da cultura nacional - humana", mostrando-se recetivo à ideia que a "educação será, pois, mais voltada para o futuro que para o passado ou presente" e coloca, na sua perspetiva, esse desígnio no contexto de um Estado neutro e de uma sociedade secular, onde prevaleçam os princípios democráticos (liberdade, igualdade, fraternidade) capazes de induzirem uma moral social, mas uma sociedade em "que os espíritos cooperem num acordo de vontades e razões, acordo feito em cada um pela sua autonomia e em todos porque essa autonomia é exatamente possível”. Os argumentos que Leonardo Coimbra esgrime com a subtileza de um filósofo, levamno a reafirmar que: "O Estado tem de limitar a sua ação à linha geral da cultura, não pode impor mais que um método, uma atitude que deixa às 
liberdades a escolha das doutrinas especulativas que melhor recebam o seu acordo", o que significa que a "educação oficial será, pois, dada no seu mínimo a todos" para "respeitar a linha do progresso cultural de que todos devem ser cooperadores", e este "ensino fundamental" é, segundo Leonardo Coimbra, "uma obrigação indeclinável da nossa Democracia".

Para além do quadro partidário germinavam movimentos de republicanos que procuravam com denodo revitalizar o objetivo demopédico. As experiências destes republicanos intelectuais começam em 1912, em torno da Renascença Portuguesa, onde, partilhando o paradigma republicano, se distanciam do positivismo e assumem posições de natureza filosófica ou estética. Nos anos vinte, concretamente em 1921, surge o projeto Seara Nova, onde os percursos dos políticos seus fundadores, são retrabalhados à luz de um pensamento estratégico de intervenção política supra partidária, a intervenção que protagonizam é feita dentro do campo republicano e, decididamente, pela República, através de uma alternativa - "espiritualista vitalista" (Raul Proença) e "racionalista crítica" (António Sérgio) -, que consiga superar a crise, com base numa elite intelectual renovada e alicerçada numa opinião pública forte (Serrão, s.d., p. 127-165).

\section{Declinações do laicismo}

A sondagem proposta pode evidenciar algumas conclusões - ou, dito de outro modo, fragmentos para entender o hibridismo do republicanismo português - que remetem, essencialmente, para a forma como o conceito de laicidade é hesitante (para se usar uma expressão cara a Jean Baubérot).

O percurso que assinalamos vai patentear (obviamente, nos limites da abordagem que abalançamos) a fragilidade da frente que o Partido Republicano Português protagonizou no combate à Monarquia. Desde os primeiros momentos da nascente República, se assiste ao estilhaçar do Partido, especialmente, quando em decisões cruciais se exigiam posições esclarecidas e consensuais. Estão nesta circunstância as situações, porventura, mais paradigmáticas dessa construção de uma sociedade. Podem-se, então, inventariar as seguintes tensões: a questão da elaboração da Constituição (Cunha, 2010; Matos, 2010;Pinto, 2010); a Lei da Separação (Matos2011; Moura, 2010); as relações com o movimento sindical com os 
seus inúmeros equívocos (Pinto, 2011; Ventura, 2010) - provavelmente, enquadrado na formação de uma República Social (Pereira, 2011; Tiago, 2010) -; a definição de uma política cultural (Melo, 2010; Rosa, 2011), e, por fim, as intrínsecas modulações que o próprio erguer de uma escola laica demonstrou ao evidenciar que o terreno escolar é, por excelência, o lugar de formação de uma "consciência comum" (para se usar um conceito caro a Émile Durkheim) - de onde irradiariam, justamente, os contornos de uma moral capaz de desenvolver o sentido da responsabilidade e romper com os interesses individuais, em suma, uma moral crítica do utilitarismo e do individualismo, centrada na "formação de sujeitos éticos que pratiquem virtudes públicas" (Rafael Díaz-Salazar). É, então, nesta dimensão que se apreende uma ressemantização - nas diferentes formações republicanas - de um repertório conceptual caro ao património ideológico republicano. Esta constatação permite inferir que, para além do diferente posicionamento (esquerda, centro, direita) dos partidos republicanos, há a manutenção de um denominador comum que confrontado com o "fator religioso" (Rafael Díaz-Salazar) - ou com o lugar que a religião ocupa nas desigualdades sociais - nos vai permitir atestar a carga dos ideologemas das diversas representações republicanas - a emergência de vocábulos e de conceitos vai possibilitar uma aproximação à própria vida da República (pacificação, tolerância, ...), mas também é encarada (pela ativa ou pela passiva) a questão laica como fazendo parte integrante da questão social, mas intrinsecamente correlacionada com a secularização e a democratização da Sociedade (de que o binómio Lei da Separação / Escola é um índice privilegiado). $\mathrm{O}$ que o nosso inquérito pode permitir concluir é que, para além de uma defesa formal do laicismo, se escondem formas muito diferentes de entender a laicidade. Esta polissemia está, certamente, presente quando confrontada com outras laicidades, como, por exemplo, a de matriz socialista em que a autonomização das reivindicações operárias é um modo de compreender como o sindicalismo se vai paulatinamente desconfessionalizando (Chanet, 2010); ou quando confrontada com o reavivar de um catolicismo intransigente, ou seja, obcecado com o laicismo - o que no oposto encontra expressão num laicismo excludente e, por consequência, não recetivo à tradição religiosa. É, justamente, neste aspeto que se pode encontrar a combinatória que tende a privilegiar o 
parlamentarismo como lugar exclusivo de aprendizagem do pluralismo, que, em certa medida, vai escamotear o direito cívico à diversidade, como estruturante da laicidade, ou seja, o modo como se pensa o processo de secularização cultural e social, significando tal posição quase um limite ao captar a autonomia do político, do religioso, do jurídico e da moral.

Tende, então, a refletir-se nos partidos republicanos uma inibição sobre o pensar essa autonomia - ou a diferença entre licitude jurídica e exigência moral - como uma aprendizagem democrática imprescindível de luta - simbólica e de transformação do mundo quotidiano - contra qualquer forma de totalitarismo ou integrismo religioso que pretenda uniformizar a sociedade. Estas são algumas das veredas que a experiência republicana portuguesa pode deixar antever e que nós, ao privilegiar a realidade política como objeto de investigação, quisemos sinalizar, certamente, não como ultima verba.

\section{REFERÊNCIAS}

ABREU, C. \& FREIRE, J. (Org. e Introdução). Adriano Botelho. Memória \& Ideário (Antologia de Textos). Angra do Heroísmo: Secretaria Regional de Educação e Cultura, 1981.

A Comissão Política do Partido Reconstituinte apresenta ao eleitorado o seu Programa, O Século, 22. Junho, p. 1-2, 1921.

AFONSO, J. A. Escolas Protestantes. Dispositivos de inserção e de regeneração. Uma reflexão sobre a realidade portuguesa de meados do séc. XIX até às primeiras décadas do séc. XX. In António Matos Ferreira \& João Miguel Almeida (Coord.), Religião e Cidadania. Protagonistas, motivações e dinâmicas sociais no contexto Ibérico (p. 547-565). Lisboa: Universidade Católica Portuguesa, 2012.

ALMEIDA, P. Tavares (Org.). Materiais para a História Eleitoral e Parlamentar Portuguesa, 1820-1926. Lisboa: Biblioteca Nacional, 2006. Disponível em: <http://purl.pt/5854/1/índex.html>. Acesso em: 19 Jan. 2012.

ANDRADE, L. O. \& TORGAL, L. R.. Feriados em Portugal. Tempos de Memória e Sociabilidade. Coimbra: Imprensa da Universidade de 
Coimbra, 2012.

ANGENOT, M. El discurso social. Los limites históricos de lo pensable y decibel. Buenos Aires: Siglo XXI Editores, 2010.

AUDINER, S. Les théories de la republique. Paris: La Découverte, 2004. ARAÚJO, A. F. O “Homem Novo" no Discurso Pedagógico de João de Barros. Ensaio de mitanálise e de mitocrítica em educação. Braga: Universidade do Minho, 1997.

ARAÚJO, P.. Miguel Bombarda. Médico e Político. Casal de Cambra: Caleidoscópio, 2007.

Ao Eleitorado Republicano. A Vitória, 26. Janeiro, p. 1, 1922.

Aos Eleitores de Lisboa. Os Candidatos Monárquicos. Correio da Manhã, 27. Janeiro, p. 1, 1927.

Ao Pais. O Programa eleitoral e administrativo do novo Governo. República, 23.Junho, p. 1, 1921.

Ao Paiz. Manifesto da União Republicana. A Luta, 3.Mai, p. 1, 1919.

BAPTISTA, P. O Filósofo Fantasma. Lúcio Pinheiro dos Santos. Sintra: Zéfiro, 2010.

BARROS, J. Educação Republicana. Paris - Lisboa: Livrarias Aillaud \& Bertrand, 1916.

. A Educação Moral na Escola Primária. Paris - Lisboa: Livrarias Aillaud \& Bertrand, 1914.

BOUISSON, F. (Dir.). Nouveau Dictionnaire de Pédagogie et d'Instruction Primaire. Paris: Librairie Hachette et Cie, 1911.

CARRILHO. D. A Liberdade de Ensino perante o Problema Moral. Depoimento de um Professor e de um Republicano. Braga: Raul Guimarães $\& C^{a} ., 1922$.

CARVALHO, D. L. Os Levantes da República (1910-1917). Resistência à laicização e movimentos populares de repertório tradicional na $1^{\mathrm{a}}$. República Portuguesa. Porto: Afrontamento, 2011.

CATROGA, F. O Republicanismo em Portugal. Da formação ao 5 de Outubro de 1910. 3. ed. Lisboa: Casa das Letras, 2010. 
CHANET, J. F. Une laïcité socialiste. Paris: Fondation Jean-Jurés, [2010]. COELHO, T. Manual Politico do Cidadão Portuguez. Prefácio de Alberto de Oliveira. Lisboa: Parceria A. M. Pereira, 1906.

COIMBRA, L. O Problema da Educação Nacional (Tese apresentada ao Congresso da Esquerda Democrática realizado em 1926). Porto: Maranus, 1926.

Conjugação Republicana - Manifesto Eleitoral. A Luta, 26.Janeiro, p. 1, 1922.

COSTA, M. J. A. \& MARCOS, R. M. F.. A Primeira República no Direito Português. Coimbra: Almedina, 2010.

CUNHA, P. F. O essencial sobre a I República e a Constituição de 1911. Lisboa: Imprensa Nacional - Casa da Moeda, 2011.

CUNHA E COSTA. A Egreja Catholica e Sidonio Paes. Coimbra: Coimbra Editora, 1921.

DIAZ-SALAZAR, R.. Laicismo y Catolicismo. Una nueva confrontación?. Claves de Razón Prática, 208, p. 64-73, 2010.

DIAZ-SALAZAR, R.. El factor católico en la politica española. Del nacionalismo al laicismo. Madrid: PPC, 2006.

DROZ, N. Manual de Instrucção Civica. Versão portugueza de João de Barros. Lisboa: Livrarias Aillaud \& Bertrand, [c. 1912].

Esquerda Democrática. À Nação [Cartaz], 1925.

Escolas Móveis - Relatório do Inspector. Boletim Oficial do Ministério da Instrução Pública, 1, p. 48-55, 1916.

FAVA, F. M.. Leonardo Coimbra e a I República. Percurso político e social de um filósofo. Coimbra: Imprensa da Universidade de Coimbra, 2008.

LEAL, E. C. O campo partidário republicano (1910-1926). Coimbra: Imprensa da Universidade de Coimbra, 2008.

MACEDO, F. N. A Neutralidade em matéria religiosa: meios de conseguila. Revista da Faculdade de Letras da Universidade do Porto, 5-6, pp. 453-468, 1923.

Manifesto do Directorio do Partido Republicano Português. O Mundo, 
17.Outubro, pp. 1-2, 1925.

MARÇAL, B. J. N. Governo de Pimenta de Castro. Um General no Labirinto. Dissertação de Mestrado (mimeo.). Lisboa: Faculdade de Letras - Universidade de Lisboa, 2010.

MARQUES, A. H. O. A Primeira República Portuguesa. Lisboa: Texto, 2010 .

Horizonte, 1988.

MATOS, L. S. A Separação do Estado e da Igreja. Concórdia e conflito entre a I República e o Catolicismo. Lisboa: D. Quixote, 2011.

. Tudo o que sempre quis saber sobre a Primeira República em 37 mil palavras. As instituições políticas portuguesas do 5 de Outubro de 1910 ao 28 de Maio de 1926. Lisboa: Imprensa de Ciências Sociais, 2010.

MELO, D. A leitura pública na I República. V. N. Famalicão: Ed. Húmus/ Centro de História da Cultura da Universidade Nova de Lisboa, 2010.

MENESES, F. R. Afonso Costa. Lisboa: Texto, 2010.

MOURA, M. L. B. A 'Guerra Religiosa' na I República. 2. ed. Revista e Aumentada (1. ed.: 2004). Lisboa: Universidade Católica Portuguesa, 2010.

NETO, V. A Primeira República portuguesa e a religião. Seara Nova, 1713, p. 8-11, 2010.

O Directorio do Partido Radical. Ao País. Lisboa, Sociedade Nacional de Tipografia, 1921.

O Programa do Deputado Presidencialista, Sr. Dr. Gomes Mota, O Século, 5. Julho, p. 1-2, 1921.

OUDINOT, V. Notas dum Inspector Escolar. Acção (Intra e Extra-Escolar). Porto: Livraria Chardron, 1915.

PARTIDO REPUBLICANO LIBERAL. Cidadão. [Folha Volante], 1921.

Partido Republicano Nacionalista. Ao País. Democracia do Sul, 3. Novembro, p. 1-2, 1925.

PARTDO REPUBLICANO PORTUGUÊS, Cidadãos!! Pela República! 
[Cartaz], 1922.

Partido Republicano Presidencialista - Comissão Política. [Folha Volante], 1921.

PEREIRA, D. O. R. As políticas sociais na Primeira República portuguesa (1910-1926). Vértice, 154, p. 20-30, 2011.

PINTASSILGO, J. O projecto educativo do republicanismo: o caso português numa perspectiva comparada. Ler história, 59, p. 183-203, 2010. PINTO, A. C. A Primeira República e os Conflitos da Modernidade (19191926). A Esquerda Republicana e o Bloco Radical. Casal de Cambra: Caleidoscópio/Comissão Nacional para as Comemorações do Centenário da República, 2011.

PINTO, R. L. (Introdução e Selecção). A Constituinte de 1911. As Grandes Polémicas. Lisboa: Universidade Lusíada Editora, 2010.

PINTO, S. F. R. Separação como modernidade: a Lei de 20 de Abril de 1911 e modelos alternativos. Dissertação de mestrado (mimeo.). Lisboa: Universidade Nova, 2008.

POINSARD, L. Portugal Ignorado. Estudo Social, Económico e Político seguido de Um Appendice Relativo aos Ultimos Acontecimentos. Porto: Magalhães \& Moniz, Lda. - Editores, 1912.

RAMOS, J. D. A Reforma do Ensino Normal - O projecto de lei. Discursos e pareceres na Câmara dos Deputados. A lei de 7 de Junho de 1914. Lisboa: Liv. Ferreira, 1915.

. \& Barros, J.. A Reforma da Instrução Primária. Primeiro projecto e sua justificação; segundo projecto e comentários. Confronto do primeiro projecto com o Decreto de 29 de Março de 1911. Porto: Tip. Costa Carregal, 1911.

República Portuguesa. Relatório do Governo apresentado às Câmaras Legislativas em 2 de Dezembro de 1913. Lisboa: Imprensa Nacional, 1913. REPÚBLICA PORTUGUESA. Relatório apresentado à Assembleia Nacional Constituinte pelo Ministro dos Negócios Estrangeiros [Bernardino Machado], Lisboa: Imprensa Nacional, 1911.

RIBEIRO, C. P. Os Outros ... a Casa Pia de Lisboa como espaço de 
inclusão da diferença. Porto: UPorto editorial, 2011.

ROSA, R. N. Ensino e Cultura Técnica e Científica em Portugal. A transição republicana. Vértice, 154, p. 66-77, 2011.

RUZ SOROA, J. M. 'España ha dejado de ser católica'. La palabra imprudente de Manuel Azaña. Claves de Razón Prática, 214, p. 24-32, 2011.

SÁ, L. \& RÊGO, M. (Coord., org. e pesquisa). Jornais republicanos: 1848-1926. Lisboa: Biblioteca Nacional / Assembleia da República, 2011. SÁ, V. Liberais \& Repúblicanos. Lisboa: Livros Horizonte, 1986.

SÉRGIO, A. Educação Cívica. Porto: Renascença Portuguesa, 1915.

SERRÃO, J.. Da "Regeneração” à República. Lisboa: Livros Horizonte, 1990.

SERRÃO, J. Portuguese Somos. Lisboa: Lisboa, s.d.

SOBRAL, M. N. Os Inquéritos Pedagógicos em 'O Século' (Escola Portuguesa na Imprensa: 1920). Revista Metáfora Educacional, (ISSN: 1809 - 2705) - versão on-line, n. 10, jun./2011, p. 64-77. Disponível em: $<$ http://www.valdeci.bio.br/revista.html >. Acesso em: 23. fevereiro. 2013. TIAGO, M. C. Bairros Sociais da I República: projectos e realizações. Ler história, 59, p. 249-272, 2010.

TORGAL, L. F. (Org. e Prefácio). Tomás da Fonseca. Religião. República. Educação. Antologia. Lisboa: Antígona, 2012.

VALENTE, V. P. (2010). A «República Velha» (1910-1917). Lisboa: Alêtheia, 2010.

VENTURA, A. Os Constituintes de 1911 e a Maçonaria. Lisboa: Círculo de Leitores/Temas e Debates, 2011.

VENTURA, A. A República e os movimentos sociais e laborais. Seara Nova, 1714, p. 3438, 2010.

Data de registro:13/05/2013

Data de aceite:08/07/2013 
ANEXO I: As diferentes sensibilidades republicanas

\begin{tabular}{|c|c|c|}
\hline $\begin{array}{l}\text { REPUBLICANISMO } \\
\text { DEMOLIBERAL }\end{array}$ & $\begin{array}{l}\text { REPUBLICANISMO } \\
\text { RADICAL }\end{array}$ & $\begin{array}{c}\text { REPUBLICANISMO } \\
\text { DEMOLIBERAL MODERADO }\end{array}$ \\
\hline $\begin{array}{l}\text { - Ideologia federalista } \\
\text { "mais fraca". } \\
\text { - Ensino laico. } \\
\text { - Elite Governamental. } \\
\text { - Leis basilares da Repú- } \\
\text { blica (Separação, Famí- } \\
\text { lia, Divórcio). } \\
\text { - 1a. Cisão: Tolerância } \\
\text { política, liberdade reli- } \\
\text { giosa. } \\
\text { - 2a. Cisão: Reforma da } \\
\text { educação, reorganização } \\
\text { económico-financeira, } \\
\text { promoção social das clas- } \\
\text { ses médias e das classes } \\
\text { trabalhadoras, Progra- } \\
\text { ma de 1891, República } \\
\text { democrática unitária, } \\
\text { descentralização, digni- } \\
\text { dade da pessoa humana, } \\
\text { sufrágio universal, re- } \\
\text { conhecimento de todas } \\
\text { as liberdades públicas e } \\
\text { privadas, sistema unica- } \\
\text { marista, sistema eleitoral } \\
\text { proporcional, prioridade } \\
\text { à instrução pública. }\end{array}$ & $\begin{array}{l}\text { - Federalismo, municipalis- } \\
\text { mo, contornos socialistas, } \\
\text { Estado unitário descentra- } \\
\text { lizado, presidencialismo, } \\
\text { intransigência face aos } \\
\text { monárquicos e ao clerica- } \\
\text { lismo, exclusão absoluta } \\
\text { de qualquer prática de en- } \\
\text { sino religioso nas escolas, } \\
\text { instrução pública com ca- } \\
\text { rácter mais prático, ensino } \\
\text { técnico. } \\
\text { - Restauração da "pureza } \\
\text { primitiva" das leis basilares } \\
\text { da República (Separação, } \\
\text { Família, Divórcio). } \\
\text { - Reforma radical. } \\
\text { - "Republicanização do re- } \\
\text { gime". } \\
\text { - Republicanismo intransi- } \\
\text { gente. }\end{array}$ & $\begin{array}{l}\text { - Educação da vontade, or- } \\
\text { dem, supremacia do poder } \\
\text { civil, liberdade de cultos, } \\
\text { reatamento das relações di- } \\
\text { plomáticas com a Santa Sé. } \\
\text { - Sidonismo: nova ordem, } \\
\text { relação estável do estado } \\
\text { laico com a Igreja Católica, } \\
\text { presidencialismo republica- } \\
\text { no, corporativismo católico } \\
\text { e integralismo lusitano, or- } \\
\text { ganização das elites. } \\
\text { - Neo-Sidonismo: área do } \\
\text { liberalismo republicano } \\
\text { autoriatário, respeito mú- } \\
\text { tuo ente o Estado e a Igreja } \\
\text { Católica, tendência para o } \\
\text { anti-parlamentarismo, pers- } \\
\text { pectiva ideológica de cariz } \\
\text { anti-liberal e corporativo, } \\
\text { intenção fascizante, nacio- } \\
\text { nalismo revolucionário. } \\
\text { - 1a. Fusão: Objetivos co- } \\
\text { muns ao campo republicano } \\
\text { - educação do povo, neutra- } \\
\text { lidade religiosa do ensino } \\
\text { público, manutenção da Se- } \\
\text { paração, alargar o sufrágio. } \\
\text { - 2a. Fusão: Nacionalismo } \\
\text { moderado, ordem, liberdade } \\
\text { das religiões, representação } \\
\text { das classes no Senado, reor- } \\
\text { ganizar o ensino. }\end{array}$ \\
\hline
\end{tabular}


ANEXO II: As formações partidárias resultantes do P.R.P

\begin{tabular}{|c|c|}
\hline $\begin{array}{l}\text { REPUBLICANISMO } \\
\text { DEMOLIBERAL }\end{array}$ & $\begin{array}{l}\text { Partido Republicano Português / Partido Democrático. } \\
(1912-1926) \text { : } \\
\text {. 1a Cisão - Partido Republicano de Reconstrução Nacional } \\
(1920) \\
\text { 2 } \text { 2 }^{\text {a }} \text { Cisão - Partido Republicano da Esquerda Democrática } \\
(1925) \\
\text {. União Nacional Republicana (1911) @ União Republicana } \\
(1912) \\
\text {. Grupo Seara Nova (1921) }\end{array}$ \\
\hline $\begin{array}{l}\text { REPUBLICANISMO } \\
\text { RADICAL }\end{array}$ & $\begin{array}{l}\text { - Aliança Nacional (1911) } \\
\text {. Partido Republicano Radical Português (1911) } \\
\text { - Integridade Lusitana (1911) } \\
\text {. Partido Reformista (1914-1918) } \\
\text {. Partido Republicano Popular (1919) } \\
\text {. Federação Republicana [Nacional] (1920-1921) } \\
\text {. Partido Republicano Radical (1922) } \\
\text { - Núcleo Republicano Reformador (1924) }\end{array}$ \\
\hline $\begin{array}{l}\text { REPUBLICANISMO } \\
\text { DEMOLIBERAL } \\
\text { MODERADO }\end{array}$ & 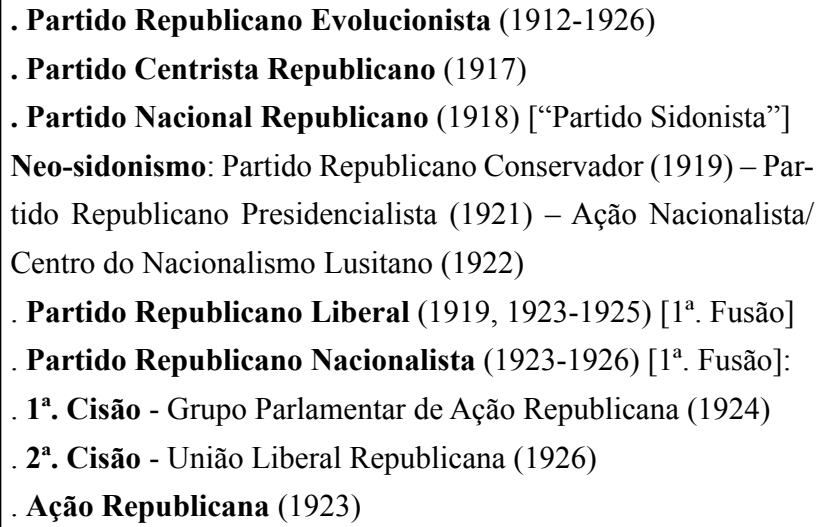 \\
\hline
\end{tabular}




\section{ANEXO III: Programas dos Partidos republicanos}

Projeto de um Programa Federalista Radical para o Partido Republicano Português (1886)

Manifesto-programa do Partido Republicano Português (1891)

Programa do Partido Republicano Português/Partido Democrático (1912)

Manifesto da Aliança Nacional (1911)

Projeto de programa do Partido Republicano Radical Português (1911)

Programa do agrupamento político Integridade Republicana (1911)

Programa da União Republicana (1912)

Programa do Partido Republicano Evolucionista (1913)

Programa do Partido Centrista Republicano 1918)

Declaração de princípios do Partido Republicano Conservador (1919)

Programa do Partido Republicano Liberal (1919)

Plataforma política do Grupo Parlamentar Popular/Partido Republicano Popular (1920)

Objetivo político da Federação Nacional Republicana (1920 ou 1921)

Manifesto do Partido Nacional Republicano Presidencialista (1921)

Proclamação do Movimento de 19 de Outubro de 1921/Outubrismo (1922)

Programa do Nacionalismo Lusitano (1922)

Manifesto do Partido Republicano Nacionalista (1923)

Programa de realização imediata do Partido Republicano Nacionalista (1924)

Programa do Partido Republicano Radical (1923)

Comunicação à Câmara dos Deputados sobre a constituição do grupo parlamentar de Ação Republicana (1923)

Manifesto-programa do Núcleo Republicano Reformador (1925)

Manifesto da União Liberal Republicana (1926)

O problema político - tese apresentada ao Congresso do Partido Republicano da Esquerda Democrática (1926) 